\title{
学会賞講演
}

\section{TOF 中性子回折による高温超伝導体の構造解析}

\author{
無機材質研究所 泉 富士夫
}

この十年ほどの間に，リートベルト法は多結晶体の構造パラメーターを精密化する強力な手段として，固体物理・化学，材 料科学、鉱物学などの分野にすっかり根をおろした，日本におけるリートベルト法の㘳及・定着には，国单のリートベルト 解析プログラム RIETAN が大きく貢献したといってよいだうう. 従来のプログラムには，(1) 最小二乗計算が安定に収束し

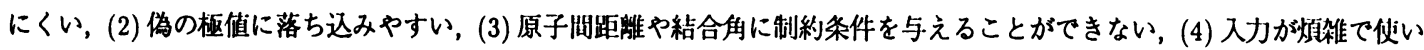
勝手が悪い，などの欠点が多く，その発展と普及を妨げる原因となっていた，筆者はアルゴリズムにさまざまな工夫をこら すことによって，これらの問題のかなりの部分を解汏した角度分散型回折法用プログラム RIETAN ${ }^{1)}$ を独自に開発し，種々 の金属・無機材料の構造精密化に応用して，その有効性を確認した，RIETAN のもっとも重要なセールス・ポイントは，段 階的精密化と Fletcher の修正 Marquardt 法の併用により全自動の精密化と安定な収束を両立させたことである.

RIETAN はさらに, 1983 年に高エネルギー物理学研究所の中性子散乱研究施設 KENS に設置された飛行時問 (time-offlight: TOF) 型粉末中性子回折装置 HRP で判定した強度データにも適用できるように改造された，TOF 中性子回折は一定 時間ごとにパルス状に飛来する白色中性子ビームを利用する。一種のエネルギー分散型回折法なので，回折角 $2 \theta$ は一定の 值に固定しておく．そしてパルス・ビームがターゲット・減速材から試料を経てカウンターに到着するまでのTOF を時間 分析装置で湘定し，一挙に全 $Q$ 空問の回折強度を集皘する．高温や高圧などの特殊環境下でのin situ 回折実験を行う場合 は，入射および散乱ビームをスリットで絞り込むことにより炉体や高压セルからのバックグラウンドをはは完全に除去でき る. またTOF 法は $0.04 \mathrm{~nm}$ もの格子面間隔の小さい反射の強度を谷易に測定できるので，構造パラメーター，とりわけ熱 振動パラメーターの精度が向上するという長所ももつ. HRPは $20 \mathrm{~K}$ 固体メタン成速材からの入射ビームを利用していたた め，回折プロファイルおよびその波辰依存性がきわめて複雑であったが，筆者はHRP 用に最適化したブロファイル閳数を 導き出し，TOF 中性子回折用の RIETAN ${ }^{2}$ を完成させた．その結果，高 $Q$ 領域での分解能がきわめて高い冷中性二源の艮 所を十分活かした粠造解析が可能となった。

1987 年の超伝導フィーバー以後は, TOF 粉末中性子回折ーリートベルト解析の組み合わせを一速の超伝導 Cu 酸化物に 適用することにより，新超伝導体の構造，格子久陥と超伝導特性との関係，構造の組成・温度・圧力依存性について侀究し， 高温超伝導体の結晶化学的性質を綿密に調べた.HRPにより得られる観測強度は非常に弱く，しかもKENS の運転期䦌は 比較的短いため，組成や温度を変えて多点のデータを収集するのは困難だった．しかし国内の有力な研究組織に試料の提供 を皘極的に呼びかけ，重要な超伝導体のほとんどをカバーするよう努めるとともに，超伝導の研究に優先的にビーム・タイ ムを割り当てた結果，装置の領弱さを考慮すれば「第異的」といってよいほどの成果を挙げることができた。

今日では $90 \mathrm{~K}$ 級超伝導体 $\mathrm{Ba}_{2} \mathrm{YCu}_{3} \mathrm{O}_{7-\delta}$ が酸素欠損三重ペロブスカイト型と呼ばれる結晶棈造をもつことはよく知られ ているが、これは 1987 年春に筆者がアルゴンヌ国立研究所やNIST とほほ同時に，悪戦苦闘の末，独立に解析したもので ある3). 正方晶 (高温相) と斜方晶(低温相)における $z=0$ 平面上の酸素の占有率と秩序化の違いを世界で初めて指摘したの

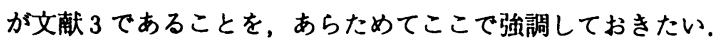


われわれは秋光らが発見した新超伝道体 $\left(\mathrm{Nd}_{1-x} \mathrm{Sr}_{x}\right)\left(\mathrm{Nd}_{1-y} \mathrm{Ce}_{y}\right) \mathrm{CuO}_{4-\delta}$ と $\left(\mathrm{Ba}_{1-x} \mathrm{Nd}_{x}\right)_{2}\left(\mathrm{Nd}_{1-y} \mathrm{Ce}_{y}\right)_{2} \mathrm{Cu}_{3} \mathrm{O}_{8+\delta}$ の棈造中に 蛍石型の構造プロックが存在することを 1989 年に見出しだ)。これらの研究が契機になり，蛍石型ブロックを含む超伝導体 の探索が盛んになり，多くの新超伝道体が芋ずる式に見つかった。このうちもっとも重要な成果が，十倉らによる電子ドー フ超伝導体 $\left(\mathrm{Nd}_{1-x} \mathrm{Ce}_{x}\right)_{2} \mathrm{CuO}_{4-6}$ の発見である.

1992 年には $\left(\mathrm{Ba}_{1-x} \mathrm{Sr}_{x}\right)_{2} \mathrm{Cu}_{1+y} \mathrm{O}_{2+2 y+z}\left(\mathrm{CO}_{3}\right)_{1-y}$ の粠造を HRTEM を併用することにより解析し，電荷槽中の格子欠陥と ホール注入の機構を解明した5)，炭酸塩フロックの存在を初めて指摘したこの研究成果は広く注目を集め，炭酸イオンを含 む超伝導体の探索を大幅に加速させた，その後，一連の炭酸塩超伝導体が次々に発見され，ついにはホウ酸イオン，硫酸イ オン,リン酸イオンを含有する超伝導体まで出現するに至った。 これらのオキソ酸イオンを含む超伝導体の発見により，超 伝導 $\mathrm{Cu}$ 酸化物の結晶化学はその領域を大幅に拡大したといって過言でない.

一連の高温超伝導体の構造解析を通して,これらに共通な構造的特徵が $\mathrm{CuO}_{2}$ 二次元伝導シートの存在であるこど)か碓 立したが，粉末中性子回折はさらに $\mathrm{CuO}_{2}$ シート間の電荷槽 (charge reservoir) 中に含まれる格子久宿の研究に造憾なくその

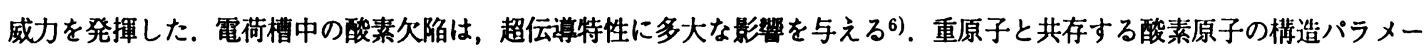
ターを精密に決定するのに，粉末中性子回折が有效なのはいうまでもない．われわれは $\mathrm{Tl}_{2} \mathrm{Ba}_{2} \mathrm{CuO}_{6+\delta}, \mathrm{TlSr}_{2} \mathrm{CaCu}_{2} \mathrm{O}_{7-\delta}$ ， $\left(\mathrm{Pb}_{1-x} \mathrm{Cu}_{x}\right) \mathrm{Sr}_{2}\left(\mathrm{Y}_{1-\nu} \mathrm{Ca}_{y}\right) \mathrm{Cu}_{2} \mathrm{O}_{7+\delta},(\mathrm{La}, \mathrm{Sr}, \mathrm{Ca})_{3} \mathrm{Cu}_{2} \mathrm{O}_{6+\delta}$ などの $\mathrm{Cu}$ 酸化物の構造を精密化し，酸素欠陥と超伝導との関係を 明快に説明することに成功した。

超伝導体に圧力をかけると，結晶を構成する各結合の強弱をかなり反映したかたちで格子が縮む．必然的に単位胞内の各 部分の綟み方は不均一となる。言い换えれば，高圧下では化学組成を一定に保ったまま，絬昆㮐造ひいては超伝桴枟移温度

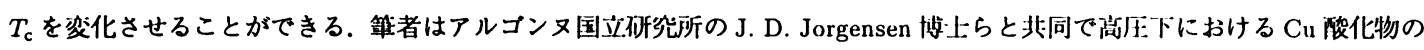

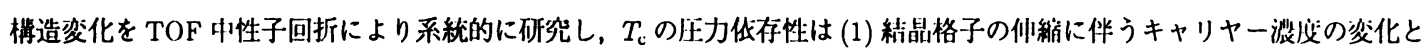

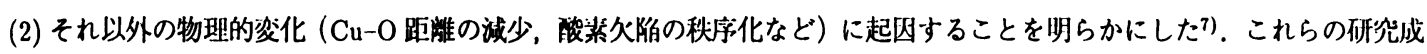
果は，超伝導体における高圧效果を考察するための基磼的結晶データとしてしばしば引用され，高く評仙されている．

KENSにはこの秋，位直敏感検出器を装伐した第二世代の数末中性子回折装置 HRP-II が設直され，単位時間当たりの観 測強度が大幅に増えた. RIETAN を初めて徹底的に改良した新版の開発もほは終了している。これからも粉末中性子回折に よる構造解析の進展と普及，さらには粉末回折分野での国際交流・貢献のために微力を尽くしていきたい.

\section{引用文献}

1) F. Izumi, "The Rietveld Method," ed. by R. A. Young, Oxford University Press, Oxford (1993), Chap. 13.

2) F. Izumi et al., J. Appl. Crystallogr., 20, 411 (1987).

3) F. Izumi et al., Jpn. J. Appl. Phys., 26, L649 (1987); 泉富士夫, 浅野㤵, 応用物理, 56, 1053 (1987).

4) F. Izumi et al., Physica $C$ (Amsterdam), 158, 440 (1989); F. Izumi et al., Physica $C$ (Amsterdam), 160, 235 (1989).

5) F. Izumi et al., Physica C (Amsterdam), 196, 227 (1992); 泉 富士夫, 化学工業, 44, 15 (1993).

6) 泉盗士夫, 日本金属学会会報, 29, 684 (1990); 泉 富士夫, 現代化学, 5 月号, 12 (1991).

7) 泉富士夫, 日本結晶学会誌, 34, 290 (1992); F. Izumi, Trans. Am. Crystallogr. Ass., in press. 